Full-length article

\title{
Growth inhibitory effect and apoptosis induced by extracellular ATP and adenosine on human gastric carcinoma cells: involvement of intracellu- lar uptake of adenosine ${ }^{1}$
}

\author{
Ming-xia $\mathrm{WANG}^{2}$, Lei-ming $\mathrm{REN}^{3}$ \\ ${ }^{2}$ The Fourth Affiliated Hospital, Hebei Medical University, Shijiazhuang 050011, China; ${ }^{3}$ School of Pharmacy, Hebei Medical University, \\ Shijiazhuang 050017, China
}

\section{Key words}

apoptosis; adenosine triphosphate; adenosine; gastric carcinoma cells; purinergic receptor

${ }^{1}$ Project supported by the Science and Technology Development Project of Hebei Province (No 20042761317).

${ }^{3}$ Correspondence to Prof Lei-ming REN, MD, PhD.

Phn 86-311-8603-3941, ext 322 .

Fax 86-311-8607-7634

E-mail ren-leiming@263.net

Received 2005-09-25

Accepted 2006-01-12

doi: $10.1111 /$ j.1745-7254.2006.00342.x

\begin{abstract}
Aim: To study the growth inhibitory and apoptotic effects of adenosine triphosphate (ATP) and adenosine (ADO) on human gastric carcinoma (HGC)-27 cells in vitro and the mechanisms related to the actions of ATP and ADO. Methods: MTT assay was used to determine the reduction of cell viability. The morphological changes of HGC-27 cells induced by ATP or ADO were observed under fluorescence light microscope by acridine orange/ethidium bromide double-stained cells. The internucleosomal fragmentation of genomic DNA was detected by agarose gel electrophoresis. The apoptotic rate and cell-cycle analysis after treatment with ATP or ADO was determined by flow cytometry. Results: ATP, ADO and the intermediate metabolites, ADP and AMP, and the agonist of purinergic receptors, reduced cell viability of HGC-27 cells at doses of 0.3 and $1.0 \mathrm{mmol} \cdot \mathrm{L}^{-1}$. The distribution of cell cycle phase and proliferation index (PI) value of HGC-27 cells changed when exposed to ATP or ADO at the concentrations of $0.1,0.3$ and $1 \mathrm{mmol} / \mathrm{L}$ for $48 \mathrm{~h}$. ATP and ADO both altered the distribution of cell cycle phase via $G_{0} / G_{1}$ - phase arrest and significantly decreased PI value. Under light microscope, the tumor cells exposed to $0.3 \mathrm{mmol} \cdot \mathrm{L}^{-1}$ ATP or ADO displayed morphological changes of apoptosis; a ladder-like pattern of DNA fragmentation obtained from HGC-27 cells treated with $0.1-1 \mathrm{mmol} \cdot \mathrm{L}^{-1} \mathrm{ATP}$ or $\mathrm{ADO}$ appeared in agarose gel electrophoresis; ATP and ADO induced the apoptosis of HGC-27 cells in a dose-dependent manner at concentrations between $0.03-1 \mathrm{mmol} \cdot \mathrm{L}^{-1}$. The maximum apoptotic rate of HGC-27 cells exposed to ATP or ADO for $48 \mathrm{~h}$ was $13.53 \%$ or $15.9 \%$, respectively. HGC-27 cell death induced by ATP or ADO was significantly inhibited by dipyridamole $\left(10 \mathrm{mmol} \cdot \mathrm{L}^{-1}\right)$, an inhibitor of adenosine transporter, but was not affected by aminophylline, a broad inhibitor of $\mathrm{P} 1$ receptors and pyridoxal-phosphate-6azophenyl-2, 4-disulphonic acid tetrasodium salt $\left(30 \mu \mathrm{mol} \cdot \mathrm{L}^{-1}\right)$, a non-selective antagonist of P2 receptors. Conclusion: Extracellular ATP and ADO reduced the cell viability, arrested cell cycle and induced apoptosis in HGC-27 cell line by intracellular uptake of ADO. One of the main routes of ATP-induced apoptosis in HGC-27 cells is through the breakdown to adenosine.
\end{abstract}

\section{Introduction}

Extracellular adenosine triphosphate (ATP) and adenosine (ADO) are important signaling molecules in both the in- tracellular and extracellular microenvironments of cells. ATP exerts transient physiologic and pharmacologic effects on the organism because it can be rapidly metabolized to ADO by ectotriphosphatase, ectodiphosphatase, and 5'-nucleotidase, 
and maintained its low physiologic concentrations. However, extracellular ATP may reach high concentrations when released exocytotically from various cell types such as neurons, platelets, basophils, and mast cells, or when released nonexocytotically from damaged cells ${ }^{[1]}$. It is well known that extracellular ATP and ADO have widespread effects on physiologic activities and play important physiologic and pathophysiologic roles in the cardiovascular system. Recently, they have been implicated in the induction of apoptosis in several cancer cell types such as human histiocytic leukemia cell line U-937 $7^{[2]}$, the mouse neuroblastoma cell line N1E-115 $5^{[3-4]}$, pancreatic cancer cells ${ }^{[5]}$, colorectal carcinoma cells ${ }^{[6]}$, prostate carcinoma cells ${ }^{[7]}$, rat pheochromocytoma cells ${ }^{[8-9]}$, and so on.

The process of programmed cell death has been suggested to play an important role in cancer diseases. Cell death by apoptosis progresses through a series of well-regulated morphological and biochemical phases, including chromatin condensation and DNA fragmentation. Recent studies have shown that ATP and ADO induces apoptosis in various cell types through receptor-mediated and non-receptor-mediated pathway, namely, the extrinsic pathway and the intrinsic pathway ${ }^{[10-11]}$. For the extrinsic pathway, $\mathrm{A}_{1}$, $\mathrm{A}_{2 \mathrm{~A}}, \mathrm{~A}_{2 \mathrm{~B}}$ and $\mathrm{A}_{3} \mathrm{ADO}$ receptors ${ }^{[12-16]}$, and $\mathrm{P} 2 \mathrm{X}_{1}, \mathrm{P} 2 \mathrm{X}_{2}, \mathrm{P} 2 \mathrm{X}_{7}$, $\mathrm{P} 2 \mathrm{Y}_{1}, \mathrm{P} 2 \mathrm{Y}_{2}$ receptors $^{[1,4,6,17-20]}$ appear to bear apoptosis in normal cells and carcinoma cells. For the intrinsic pathway, extracellular ATP and ADO seem to induce apoptosis in epithelial cancer cells originated from the breast, the colon, and the ovary or neuroblastoma cells by the conversion of ATP to $\mathrm{ADO}$ and intracellular uptake of $\mathrm{ADO}^{[3,21]}$.

We have investigated the antiproliferation effects of extracellular ATP and ADO on human gastric cell line, HGC-2 $7^{[22]}$. In an attempt to gain more insight into the mechanism of ATP- and ADO-induced apoptosis in tumor tissue, we report that ATP and ADO can induce apoptosis in HGC-27 cells, in which cellular uptake of ADO plays an important role. In present study we observed the growth inhibitory and apoptotic effects of ATP and its final metabolite, ADO, on the human undifferentiated gastric cancer (HGC)-27 cells.

\section{Materials and methods}

Drugs and reagents $\mathrm{ATP}, \mathrm{ADO}, \mathrm{ADO}$ diphosphate (ADP), adenosine monophosphate (AMP), acridine orange (AO), ethidium bromide (EB), 3-(4,5-dimethylthiazol-2-yl)-2, 5-diphenyl tetrazolium bromide (MTT), aminophylline and dipyridamole were purchased from Sigma. RNase, SDS, proteinase K, trypsin and agarose were purchased from SinoAmerican Biotec. RPMI 1640 medium was purchased from
GIBCO. Fetal bovine serum (FBS) was purchased from Hangzhou Sijiqing Biotec. Pyridoxal-phosphate-6azophenyl-2, 4-disulphonic acid tetrasodium salt (PPADS) was purchased from Tocris Cookson. ATP, ADP, AMP and ADO were dissolved in sterile phosphate-buffered saline (PBS) and stored at $-20^{\circ} \mathrm{C}$.

Cell culture HGC-27 cells, obtained from Shanghai Cell Database of Chinese Academy of Sciences, were cultured in RPMI 1640 medium supplemented with 10\% (v/v) FBS, 100 $\mathrm{U} \cdot \mathrm{mL}^{-1}$ of penicillin, and $100 \mu \mathrm{g} \cdot \mathrm{mL}^{-1}$ streptomycin at $37{ }^{\circ} \mathrm{C}$ in a humidified, $\mathrm{CO}_{2}$-controlled (5\%) incubator.

MTT assays The cell viability was determined by MTT assay $^{[23]}$. The HGC-27 cells in exponential phase of growth were harvested and seeded in 96-well plates (Costar, USA) at a density of 10000 cells per well, and cultured for $24 \mathrm{~h}$. ATP, ADP, AMP or ADO $\left(0.3\right.$ and $\left.1 \mathrm{mmol} \cdot \mathrm{L}^{-1}\right)$ and control (PBS) was then added into the wells, and incubated continuously for $48 \mathrm{~h}$ at $37^{\circ} \mathrm{C}$ with $5 \% \mathrm{CO}_{2}$. A $20 \mu \mathrm{L}$ sample of MTT solution ( $5 \mathrm{~g} \cdot \mathrm{L}^{-1}$ dissolved in PBS) was added to each well and the plates were incubated at $37^{\circ} \mathrm{C}$ for $4 \mathrm{~h}$. The supernatant was discarded and $150 \mu \mathrm{L}$ dimethylsulfoxide was added to dissolve the blue insoluble MTT formazan produced by mitochondrial succinate dehydrogenase. The absorbance was measured at $490 \mathrm{~nm}$ in a spectrophotometer (Zhengzhou Bosai Biotech, ht2010), the negative control well contained medium only. Other inhibitors such as aminophylline, PPADS and dipyridamole were added to the medium $30 \mathrm{~min}$ before incubating cells with ATP or ADO. All determinations were performed in quadruplicate and each experiment was repeated at least three times.

Morphological assessment of apoptotic cells induced by ATP or ADO Morphological assessments of apoptotic cells were carried out using the $\mathrm{AO} / \mathrm{EB}$ double-staining method ${ }^{[24]}$. HGC-27 cells in exponential phase of growth were harvested and seeded in a $25 \mathrm{~mL}$ cultured flask. The cells were incubated for $24 \mathrm{~h}$ at $37^{\circ} \mathrm{C}$ with $5 \% \mathrm{CO}_{2}$, and then treated with $0.3 \mathrm{mmol} \cdot \mathrm{L}^{-1} \mathrm{ATP}$ or ADO for $48 \mathrm{~h}$. Freshly isolated HGC-27 cells $\left(1 \times 10^{6}\right)$ were harvested in an Eppendorf centrifuge tube, centrifuged for $5 \mathrm{~min}$ at $1000 \mathrm{rpm}$ and suspended in PBS containing fluorescence dye $\mathrm{AO} / \mathrm{EB}$ ( $\mathrm{AO}$ and $\mathrm{EB}$ were both at the concentration of $100 \mathrm{mg} \cdot \mathrm{L}^{-1}$ in PBS). The cells were prepared and dropped on slides. The morphology of the cells was observed under fluorescence light microscope (UFX- II ; Nikon, Japan) and photographed.

Agarose gel electrophoresis of DNA ${ }^{[25]}$ After treatment with $\operatorname{ATP}$ or $\operatorname{ADO}\left(0.03,0.1,0.3\right.$, and $\left.1 \mathrm{mmol} \cdot \mathrm{L}^{-1}\right)$ for $72 \mathrm{~h}$, HGC-27 cells $\left(1 \times 10^{6}\right)$ were harvested in an Eppendorf centrifuge tube and washed twice with PBS. The cells were resuspended in a cell lysis buffer $(50 \mathrm{mmol} / \mathrm{L}$ Tris-HCl buffer, 20 
mmol/LEDTApH 8.0, 1\% SDS) and then mixed by vortexing. After the cells were left to stand for $30 \mathrm{~min}$ on ice, proteinase $\mathrm{K}$ was added at a final concentration of $0.25 \mathrm{~g} \cdot \mathrm{L}^{-1}$. The cell lysates were incubated at $37{ }^{\circ} \mathrm{C}$ overnight in a water bath, and RNase was added at a final concentration of $0.5 \mathrm{~g} \cdot \mathrm{L}^{-1}$ and incubated at $37^{\circ} \mathrm{C}$ for $1 \mathrm{~h}$. The lysates were mixed with an equal volume of Tris-saturated phenol $(1: 1, v / v)$ and mildly shaken for $30 \mathrm{~min}$. The mixture was centrifuged at $3000 \mathrm{rpm}$ for $10 \mathrm{~min}$ at room temperature to separate the aqueous phase from the organic phase. Extraction of each aqueous phase was repeated, using the Tris-saturated phenol/chloroform/ isopropanol $(25: 24: 1, v / v)$ mixture. The aqueous phase was further extracted with an equal volume of chloroform. Two volumes of ice-cold ethanol and 0.1 volume of $3 \mathrm{~mol} \cdot \mathrm{L}^{-1} \mathrm{NaAc}$ precipitated DNA were mixed in the final aqueous phase. At this point, the mixture could be stored overnight. DNA was recovered by centrifugation at $13000 \mathrm{rpm}$ for $20 \mathrm{~min}$ in an Eppendorf centrifuge tube. The supernatant was discarded, the DNA pellet was washed once with $70 \%$ ethanol, air-dried, and then redissolved in an appropriate volume of deionized distilled-water and electrophoresed for $3 \mathrm{~h}$ at a constant voltage of $60 \mathrm{mV}$ on a $1.8 \%$ agarose gel containing $0.5 \mathrm{mg} \cdot \mathrm{L}^{-1} \mathrm{~EB}$, using an electrophoresis buffer $\left(40 \mathrm{mmol} \cdot \mathrm{L}^{-1}\right.$ Tris/acetate buffer, $1 \mathrm{mmol} \cdot \mathrm{L}^{-1}$ EDTA, $\mathrm{pH}$ 8.0). Each DNA sample contained bromophenol blue as a front-running dye. Ladder formation of oligonucleosomal DNA was made visible by ultraviolet transillumination and photographed using a Gel Imaging System (PE Company, USA).

Determination of apoptosis by flow cytometric analysis After the cells were incubated with the different concentration of ATP or ADO for $48 \mathrm{~h}$, they were harvested by centrifugation, washed with ice-cold PBS once and fixed in $70 \%$ ethanol at $4{ }^{\circ} \mathrm{C}$ overnight. The cells were then washed once with ice-cold PBS and resuspended in PBS ( $\mathrm{pH} 7.4)$ containing $0.5 \%$ pepsin, $5 \mathrm{mg} \cdot \mathrm{L}^{-1} \mathrm{~EB}$ and RNase at room temperature for $30 \mathrm{~min}$. Finally cells were analyzed by flow cytometry on a FACS420 (Becton Dickinson, USA) equipped with an argon ion laser (488 nm), using the HP-300 Consort 30 software to determine percentage of the apoptotic cells and the proportion of cells in $\mathrm{G}_{0} / \mathrm{G}_{1}, \mathrm{~S}, \mathrm{G}_{2} / \mathrm{M}$ phases of the cell cycle. The proliferation index (PI) of cells was calculated by the following formula:

$$
\operatorname{PI}(\%)=\frac{\mathrm{S}+\mathrm{G}_{2} / \mathrm{M}}{\mathrm{G}_{0} / \mathrm{G}_{1}+\mathrm{S}+\mathrm{G}_{2} / \mathrm{M}} \times 100 \%
$$

Statistical analysis The data shown were mean values of at least three independent experiments and expressed as mean \pm SD. Statistical analysis was performed by one-way
ANOVA and the Student's $t$-test, using statistical software SPSS 10.0. Statistical significance was set at a level of $P<0.05$.

\section{Results}

Effects of ATP or ADO on the cell cycle and PI of HGC27 cells The cell cycle phase and PI value of HGC-27 cells changed, when exposed to ATP or ADO at concentrations of $0.03,0.1,0.3,1 \mathrm{mmol} \cdot \mathrm{L}^{-1}$ for $48 \mathrm{~h}$. The proportion of cells in the $\mathrm{G}_{0} / \mathrm{G}_{1}$ - phase of cell cycle was significantly increased, Sphase of cells and PI value were significantly decreased after sustained incubation of HGC-27 cells with ATP or ADO $\left(0.1,0.3,1 \mathrm{mmol} \cdot \mathrm{L}^{-1}\right)$. The proportion of cells in $\mathrm{G}_{2} / \mathrm{M}$-phase of cell cycle was significantly decreased, when exposed to $\operatorname{ATP}\left(0.1,0.3,1 \mathrm{mmol} \cdot \mathrm{L}^{-1}\right)$ or $\operatorname{ADO}\left(0.1,0.3 \mathrm{mmol} \cdot \mathrm{L}^{-1}\right)$. These data suggest that ATP and ADO inhibited the cell proliferation via $\mathrm{G}_{0} / \mathrm{G}_{1}$ - phase delay (Table 1 and Figure $1 \mathrm{~A}, 1 \mathrm{~B}$ ).

Table 1. Effects of ATP or ADO on the PI value of HGC-27 cells. $n=3$. Mean \pm SD. ${ }^{\mathrm{b}} P<0.05,{ }^{\mathrm{c}} P<0.01$ vs control group.

\begin{tabular}{rlc}
\hline Concentration $/ \mathrm{mmol} \cdot \mathrm{L}^{-1}$ & $\mathrm{PI}(\%)$ \\
\hline ATP & 0 & $36.58 \pm 3.06$ \\
& 0.03 & $31.36 \pm 3.36$ \\
& 0.1 & $17.86 \pm 3.21^{\mathrm{c}}$ \\
& 0.3 & $16.13 \pm 3.03^{\mathrm{c}}$ \\
& 1.0 & $14.53 \pm 2.35^{\mathrm{c}}$ \\
ADO & 0 & $32.91 \pm 3.35$ \\
& 0.03 & $30.87 \pm 2.63$ \\
& 0.1 & $15.47 \pm 3.89^{\mathrm{c}}$ \\
0.3 & $14.88 \pm 3.27^{\mathrm{c}}$ \\
1.0 & $19.69 \pm 3.09^{\mathrm{c}}$ \\
\hline
\end{tabular}

Morphological changes of HGC-27 cells induced by ATP or ADO Under fluorescence light microscope, the tumor cells exposed to $0.3 \mathrm{mmol} \cdot \mathrm{L}^{-1}$ ATP or ADO displayed morphological changes of apoptosis by AO/EB double-staining, such as cell shrinkage, chromatin condensation, cell nuclear fragmentation, cell nucleous disappearance, increased nuclei fluorescence or labeled orange or red-orange color (Figure 2A-2C).

Agarose gel electrophoresis results of HGC-27 cells induced by ATP or ADO By the agarose gel electrophoresis, a ladder-like pattern of DNA fragmentation obtained from HGC-27 cells treated with $0.1-1 \mathrm{mmol} \cdot \mathrm{L}^{-1}$ ATP or ADO appeared in agarose gel electrophoresis, indicating that ATP and ADO induced apoptosis of HGC-27 tumor cells (Figure 3A, 3B). 

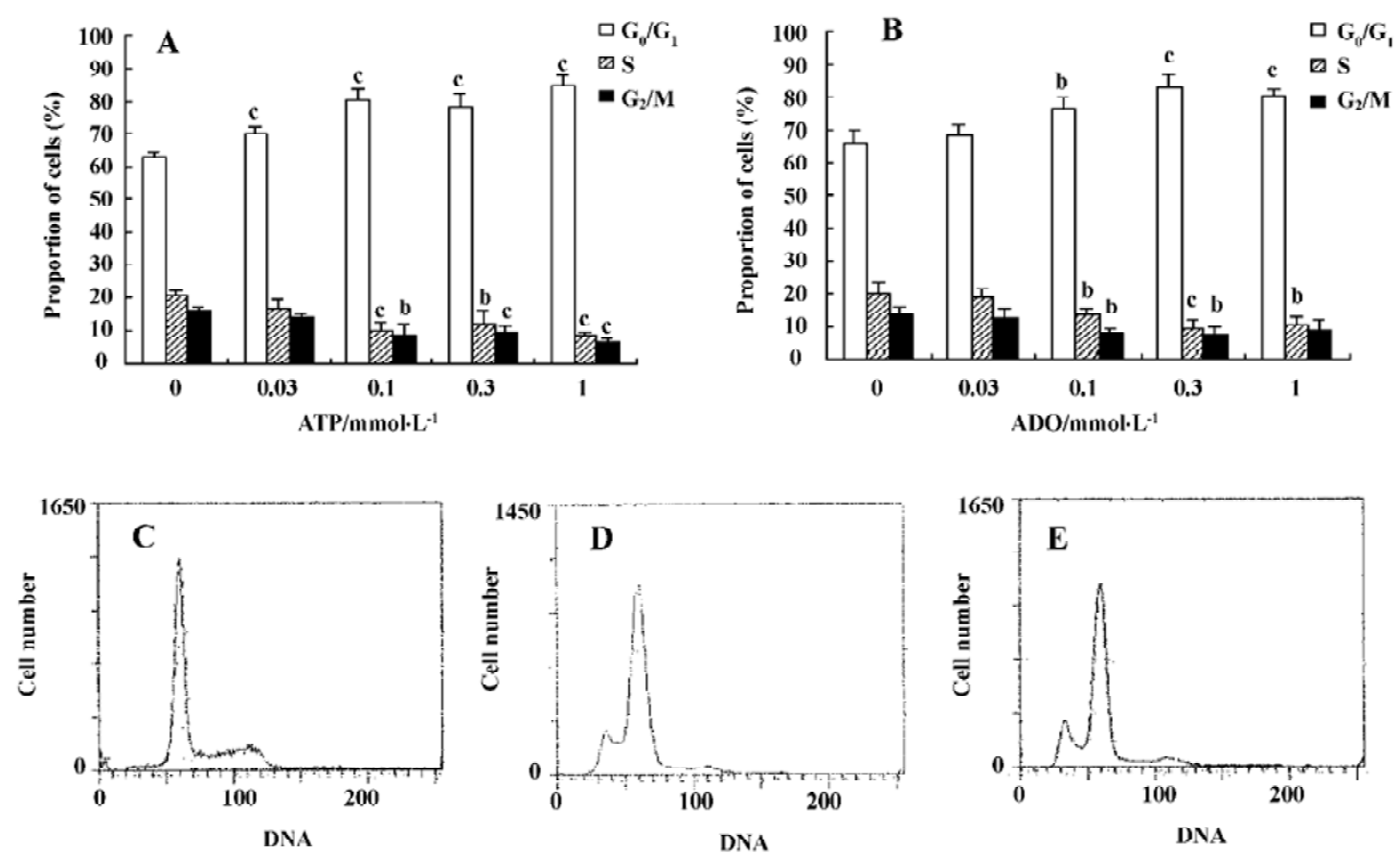

Figure 1. The distributions of cell-cycle phase of HGC-27 cells treated with ATP (A) or ADO (B) at concentrations of 0 , $0.03,0.1,0.3$, and $1 \mathrm{mmol} \cdot \mathrm{L}^{-1} \cdot \mathrm{G}_{1}$ arrest of $\mathrm{HGC}-27$ cells detected by flow cytometry without treatment (C) and with $1 \mathrm{mmol} \cdot \mathrm{L}^{-1} \mathrm{ATP}(\mathrm{D})$ or ADO (E). $n=3$. Mean \pm SD. ${ }^{\mathrm{b}} P<0.05,{ }^{\mathrm{c}} \mathrm{P}<0.01$ vs $0 \mathrm{mmol} \cdot \mathrm{L}^{-1}$.
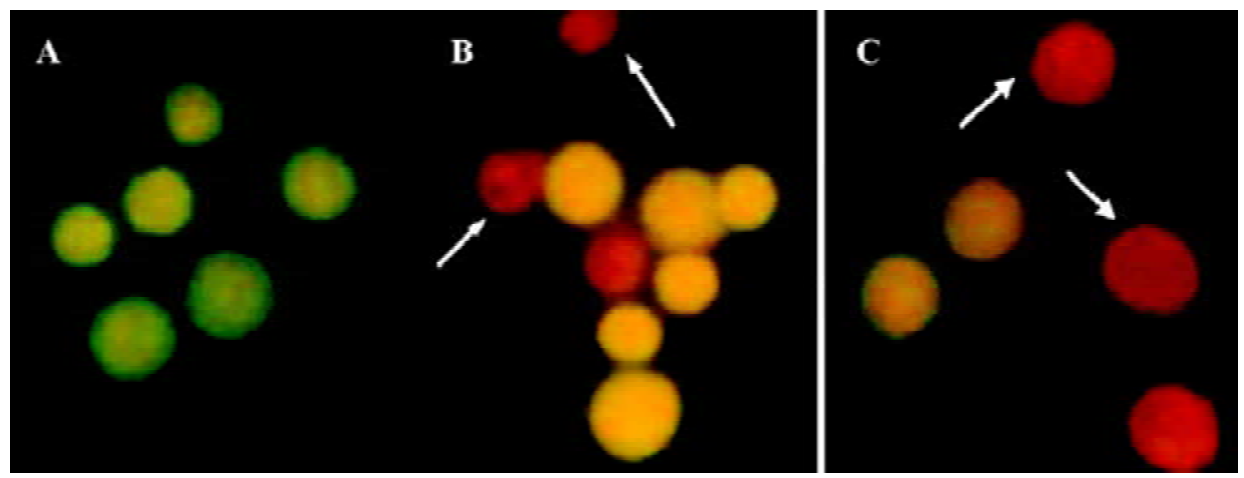

Figure 2. Fluorescence micrographs of HGC-27 cells incubated for $48 \mathrm{~h}$ without treatment (A) and with $0.3 \mathrm{mmol} \cdot \mathrm{L}^{-1}$ adenosine triphosphate (B) or adenosine $(\mathrm{C})(\times 400)$. AO/EB double-stained nuclei of cells without treatment had normal morphology, whereas the nuclei of most cells treated with adenosine triphosphate or adenosine were condensed and fragmented (arrow).

\section{Apoptotic rate of HGC-27 cells induced by ATP or ADO} The method used for this part was the analysis of the sub- $\mathrm{G}_{1}$ peak in the cell cycle. ATP or ADO induced the apoptosis of HGC-27 cells in a dose-dependent manner at concentrations between $0.03-1 \mathrm{mmol} \cdot \mathrm{L}^{-1}$ for $48 \mathrm{~h}$. The apoptotic rate of HGC27 cells treated with ATP or ADO were markedly higher than the control. The maximum apoptotic rate of HGC-27 cells exposed to ATP or ADO $\left(1 \mathrm{mmol} \cdot \mathrm{L}^{-1}\right)$ for $48 \mathrm{~h}$ was
$(13.53 \pm 1.52) \%$ or $(15.90 \pm 1.15) \%$, respectively (Table 2 and Figure 4A-4E).

Effects of ATP metabolites, ADO-uptake inhibitors and antagonists of $P$ receptors on cell viability The effects of ADP and AMP on HGC-27 cells were examined to find out whether the metabolites of ATP also inhibit the growth of HGC-27 cells. Both ADP and AMP reduced cell viability (Figure 5). We previously mentioned that ADO also caused 
Table 2. Apoptosis of HGC-27 cells induced by extracellular ATP or ADO. HGC-27 cells were treated with ATP or ADO for $48 \mathrm{~h}$. Sub-G peak in the cell cycle was analyzed by flow cytometry. $n=3$. Mean $\pm \mathrm{SD}$. ${ }^{\mathrm{b}} P<0.05,{ }^{\mathrm{c}} P<0.01 \mathrm{vs}$ control $\left(0 \mathrm{mmol} \cdot \mathrm{L}^{-1}\right)$.

\begin{tabular}{cc}
\hline Concentration $/ \mathrm{mmol} \cdot \mathrm{L}^{-1}$ & Apoptotic rate $(\%)$ \\
\hline AT P 0 & $2.23 \pm 0.32$ \\
0.03 & $3.89 \pm 0.29$ \\
0.1 & $7.30 \pm 1.01^{\mathrm{c}}$ \\
0.3 & $11.53 \pm 1.25^{\mathrm{c}}$ \\
1.0 & $13.53 \pm 1.52^{\mathrm{c}}$ \\
ADO 0 & $2.80 \pm 0.87$ \\
0.03 & $6.47 \pm 0.70^{\mathrm{b}}$ \\
0.1 & $9.33 \pm 1.72^{\mathrm{c}}$ \\
0.3 & $16.63 \pm 1.14^{\mathrm{c}}$ \\
1.0 & $15.90 \pm 1.15^{\mathrm{c}}$ \\
\hline
\end{tabular}

apoptosis in these cells. Therefore, the inhibitors that were able to block ADO-induced apoptosis were tested to investigate the involvement of ADO in ATP-induced apoptosis. Dipyridamole is an inhibitor of the nucleoside transporter and blocks the transport of ADO into the cell. We showed that this inhibitor $\left(10 \mu \mathrm{mol} \cdot \mathrm{L}^{-1}\right)$ was able to block ATP- and ADO-induced apoptosis in HGC-27 cells. The antagonists of $\mathrm{P} 1$ and $\mathrm{P} 2$ receptors, aminophylline and PPADS, were used. Both were non-selective antagonists of $P$ receptors. Neither aminophylline $\left(0.1 \mathrm{mmol} \cdot \mathrm{L}^{-1}\right)$ nor PPADS $\left(30 \mu \mathrm{mol} \cdot \mathrm{L}^{-1}\right)$ were able to block the apoptosis induced by ATP and ADO (Figure 6).

\section{Discussion}

ATP and its related compounds are widespread transmitters for extracellular communication in many cell types. By
$\mathbf{A}$

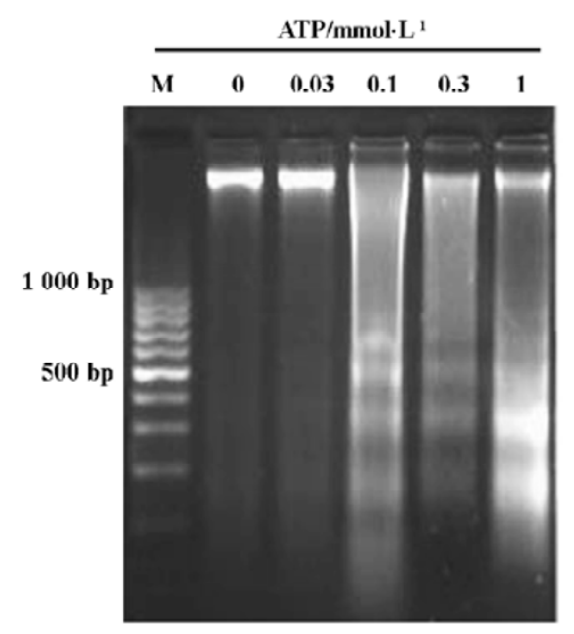

B

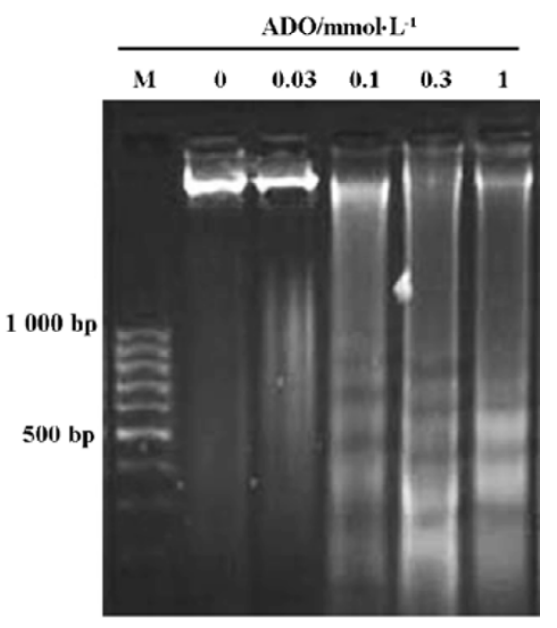

Figure 3. Agarose gel electrophoresis of DNA extracted from the apoptotic HGC-27 cells treated with $0,0.03,0.1$, 0.3 and $1 \mathrm{mmol} \cdot \mathrm{L}^{-1}$ ATP (A) or ADO (B) for $72 \mathrm{~h}$. Lane M: marker.
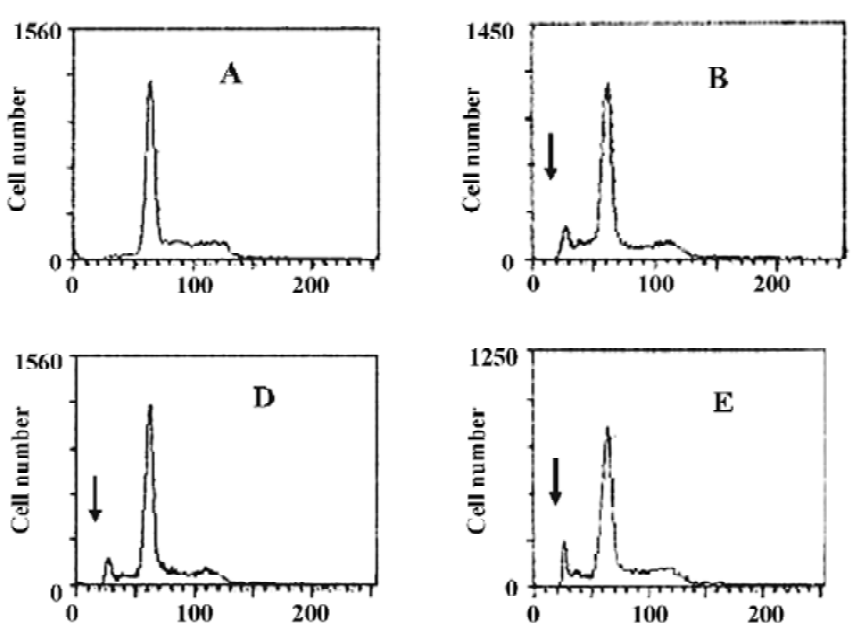

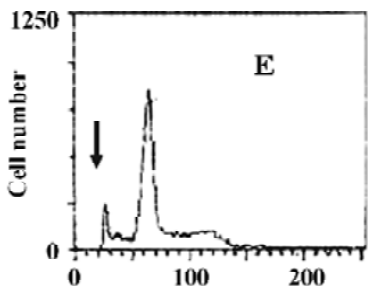

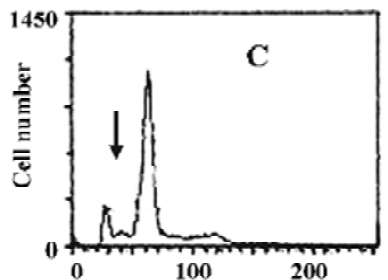

Figure 4. ATP- or ADO-induced apoptosis of HGC-27 cells detected by flow cytometry. Sub- $\mathrm{G}_{1}$ peak in the cell cycle (arrow shown) was analyzed. A, control; B, ADO $0.1 \mathrm{mmol} \cdot \mathrm{L}^{-1}$ for $48 \mathrm{~h}$; $\mathrm{C}$, ADO $1 \mathrm{mmol} \cdot \mathrm{L}^{-1}$ for $48 \mathrm{~h}$; D, ATP $0.1 \mathrm{mmol} \cdot \mathrm{L}^{-1}$ for $48 \mathrm{~h}$; E, ATP $1 \mathrm{mmol} \cdot \mathrm{L}^{-1}$ for $48 \mathrm{~h}$. 


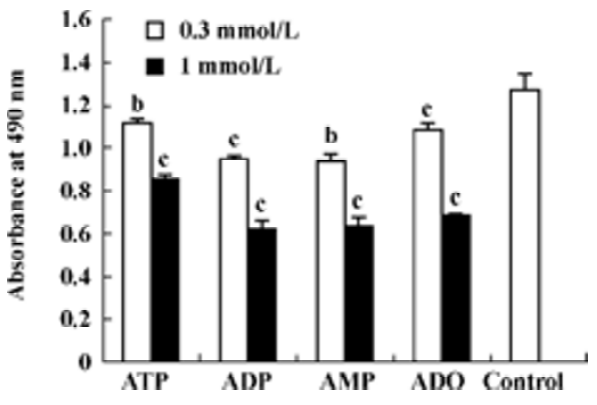

Figure 5. Growth inhibitory effects of several agonists exposed to HGC-27 cells for 48 h. $n=4$. Mean \pm SD. ${ }^{\mathrm{b}} P<0.05,{ }^{\mathrm{c}} P<0.01$ vs control.
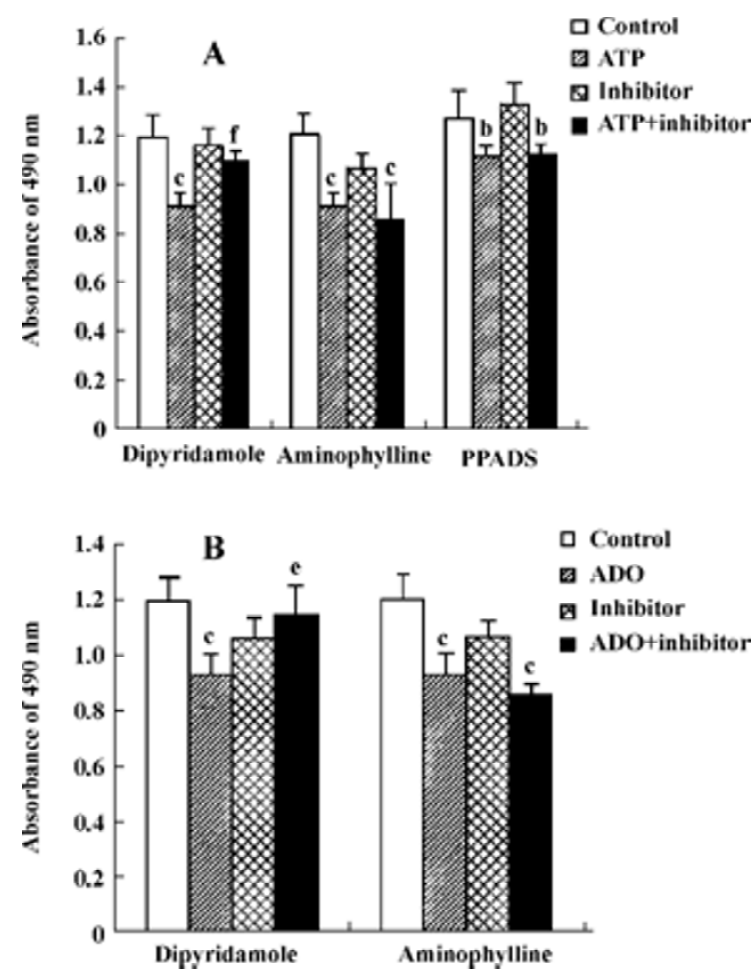

Figure 6. Effects of inhibitors, dipyridamole $10 \mu \mathrm{mol} \cdot \mathrm{L}^{-1}$, aminophylline $\left(100 \mu \mathrm{mol} \cdot \mathrm{L}^{-1}\right)$ and PPADS $\left(30 \mu \mathrm{mol} \cdot \mathrm{L}^{-1}\right)$ on $0.3 \mathrm{mmol} \cdot \mathrm{L}^{-1}$ ATP (A) and ADO (B) in HGC-27 cells. $n=4$. Mean \pm SD. ${ }^{\mathrm{b}} P<0.05$, ${ }^{\mathrm{c}} P<0.01$ vs control; ${ }^{\mathrm{e}} P<0.05,{ }^{\mathrm{f}} P<0.01$ vs ATP or ADO alone.

growth inhibition and programmed cell death were previously considered to be mediated mainly by $\mathrm{P} 1$-receptors and $\mathrm{P} 2$-receptors ${ }^{[1,4,6,10,17-20]}$. Here we provide evidence that extracellular ATP induces apoptosis and causes cell-cycle arrest in human undifferentiated gastric cancer cells, and that ADO plays an important role in this.

In the present study, the HGC-27 cell line was chosen to study the possible role of ATP and ADO in human gastric cancer diseases. Our results show that ATP and ADO reduced cell viability, caused cell arrest and induced apoptosis in this cell line. Therefore, we investigated the mechanisms involved, in particular the role of ATP and ADO receptors and ADO transporters. We assessed which of the $\mathrm{P}$ receptors were present in HGC-27 cells and also whether nucleoside transporters were present. We used a series of inhibitors, including antagonists of $\mathrm{P} 1$ receptors and $\mathrm{P} 2$ receptors (ie, aminophylline and PPADS, respectively) and a blocker of ADO transporters, dipyridamole ${ }^{[3,4,26]}$. The effects of ATP and ADO on HGC-27 cell death were not affected by aminophylline and PPADS, indicating that $\mathrm{P} 1$ and $\mathrm{P} 2$ receptors might not mediate them. In contrast, they were significantly inhibited by dipyridamole, suggesting that ADO transporter might play an important role on the apoptosis induced by ATP and ADO.

Apoptosis induced by ADO in GT3-TKB human gastric cancer cells has already been suggested by Saitoh et al, who determined the effects of the $\mathrm{ADO}\left(0.1-20 \mathrm{mmol} \cdot \mathrm{L}^{-1}\right)$ on mitochondrial membrane potentials ${ }^{[27]}$. They demonstrated that ADO-induced GT3-TKB cell death was significantly inhibited by dipyridamole. Their results also rule out the possibility for the implication of $\mathrm{P} 1$ receptors. But the effects of ATP on GT3-TKB cells were not involved in their studies. Other studies, however, showed that some subtypes of $\mathrm{P} 2$ receptor had been implicated in the induction of apoptosis in several cell lines, such as $\mathrm{P} 2 \mathrm{X}_{7}$ receptor in macrophages, microglial and dendritic cells; $\mathrm{P} 2 \mathrm{X}_{2}$ receptor in rat pheochromocytoma cells, $\mathrm{PC} 12 ; \mathrm{P}_{2} \mathrm{Y}_{2}$ receptor in colorectal carcinoma cell lines (HT29, Colo320 DM) and oesophageal cancer cells, Kyse-140 ${ }^{[4,6,17-19]}$. Abbracchio et $a l^{[29]}$ and Kohno et $a l^{[16]}$ also suggested the involvement of the $\mathrm{A}_{3}$ receptor in ADOinduced apoptosis using 2-Cl-IB-MECA (in rat astrocytes and the human promyelocytic leukemia cell line HL-60 cells, respectively). Both studies used high-agonist concentrations $\left(10 \mathrm{mmol} \cdot \mathrm{L}^{-1}\right)$, rendering a selective effect question.

Normally, ATP is very rapidly broken down to ADP and AMP, and ADO is the final metabolite. Schrier et $a l^{[4]}$ reported, ATP breakdown in a medium without cells was not as fast as that in medium with cells $\left(t_{1 / 2}: 4 \mathrm{~h}\right.$ vs $\left.30 \mathrm{~min}\right)$. ATP itself was completely broken down by N1E-115 cells in 60-120 min. We have shown that ADO could cause apoptosis in this cell line. ATP- and ADO-induced apoptosis were decreased by the inhibition of ADO-uptake using the nucleoside transport blocker dipyridamole. These results suggest that ATP induces apoptosis in HGC-27 cells via extracellular breakdown to ADO, and extracellular ATP and ADO induces apoptosis by their uptake into cells through ADO transporters. Thus, it was argued that the effects of ATP and ADO might be subsequent to the uptake of ADO by the cells. However, we could not exclude the possibility that the 
mechanism of apoptosis induced by ATP and ADO might also be due to the possible involvement of other routes as most antagonists of $\mathrm{P}$ receptors to date are non-selective and have other pharmacological effects. Therefore, further pathways leading to ATP- and ADO-induced apoptosis in HGC-27 cells need to be identified. Whether these same effects occur in vivo is yet to be established.

Additionally, Lu et $a l^{[28]}$ reported growth inhibition of ATP $(0.23 \mathrm{mg} / \mathrm{mL})$ on MGC-803 human gastric cancer cells. It was found that ATP inhibited the proliferation and arrested cell cycle in the S-phase. Our results showed that ATP arrested cell cycle in the $\mathrm{G}_{0} / \mathrm{G}_{1}$ phase. The reason why our results were not in agreement with those of $\mathrm{Lu}$ et $a l^{[28]}$ may be that we chose different kinds of gastric-cancer cell lines.

In conclusion, our data shows that extracellular ATP and ADO reduce cell viability, cause cell-cycle arrest and induce apoptosis. P receptors may not play a major role in ATP- and ADO-induced apoptosis in HGC-27 cells, but the uptake of $\mathrm{ADO}$ is required for apoptosis in this cell line. These data show that extracellular ATP and ADO are potent inducers of apoptosis. This makes ATP and ADO important compounds to consider when examining apoptosis in cancer diseases. We think that the investigation of further effects of ATP and ADO on tumor cells may provide innovative treatment strategies for gastric cancer.

\section{References}

1 Nihei OK, de Carvalho AC, Savino W, Alves LA. Pharmacologic properties of $\mathrm{P}_{2 Z} / \mathrm{P} 2 \mathrm{X}_{7}$ receptor characterized in murine dendritic cells: role on the induction of apoptosis. Blood 2000; 96: 996-1005.

2 Schneider C, Wiendl H, Ogilvie A. Biphasic cytotoxic mechanism of extracellular ATP on U-937 human histiocytic leukemia cells: involvement of adenosine generation. Biochim Biophys Acta 2001; 1538: 190-205.

3 Schrier SM, van Tilburg EW, van der-Meulen H, Ijzerman AP, Mulder GJ, Nagelkerke JF. Extracellular adenosine-induced apoptosis in mouse neuroblastoma cells: studies on involvement of adenosine receptors and adenosine uptake. Biochem Pharmacol 2001; 61: 417-25.

4 Schrier SM, Florea BI, Mulder GJ, Nagelkerke JF, Ijzerman AP. Apoptosis induced by extracellular ATP in the mouse neuroblastoma cell line N1E-115: studies on involvement of P2 receptors and adenosine. Biochem Pharmacol 2002; 63: 1119-26.

5 Yamada T, Okajima F, Akbar M, Tomura H, Narita T, Yamada T, et al. Cell cycle arrest and the induction of apoptosis in pancreatic cancer cells exposed to adenosine triphosphate in vitro. Oncol Rep 2002; 9: 113-7.

6 Hopfner M, Maaser K, Barthel B, von Lampe B, Hanski C, Riecken EO, et al. Growth inhibition and apoptosis induced by $\mathrm{P}_{2} \mathrm{Y}_{2}$ receptors in human colorectal carcinoma cells: involvement of intracellular calcium and cyclic adenosine monophosphate. Int $\mathrm{J}$ Colorectal Dis 2001; 16: 154-66.
7 Janssens R, Boeynaems JM. Effects of extracellular nucleotides and nucleosides on prostate carcinoma cells. Br J Pharmacol 2001; 132: 536-46.

8 Sun AY, Chen YM. Extracellular ATP-induced apoptosis in PC12 cells. Adv Exp Med Biol 1998; 446: 73-83.

9 Bronte V, Macino B, Zambon A, Rosato A, Mandruzzato S, Zanovello $\mathrm{P}$, et al. Protein tyrosine kinases and phosphatases control apoptosis induced by extracellular adenosine 5'triphosphate. Biochem Biophys Res Commun 1996; 218: 344-51.

10 Ferre S, Fredholm BB, Morelli M, Popoli P, Fuxe K. Adenosinedopamine receptor-receptor interactions as an integrative mechanism in the basal ganglia. Trends Neurosci 1997; 20: $482-7$.

11 Khoa ND, Montesinos MC, Reiss AB, Delano D, Awadallah N, Cronstein $\mathrm{BN}$. Inflammatory cytokines regulate function and expression of adenosine $\mathrm{A}_{2 \mathrm{~A}}$ receptors in human monocytic THP-1 cells. J Immunol 2001; 167: 4026-32.

12 Trincavelli ML, Falleni A, Chelli B, Tuscano D, Costa B, Gremigni $\mathrm{V}$, et al. $\mathrm{A}_{2 \mathrm{~A}}$ adenosine receptor ligands and proinflammatory cytokines induce PC 12 cell death through apoptosis. Biochem Pharmacol 2003; 66: 1953-62.

13 Bohm SK, Grady EF, Bunnett NW. Regulatory mechanisms that modulate signalling by G-protein-coupled receptors. Biochem J 1997; 322 ( Pt 1): 1-18.

14 Wakade TD, Palmer KC, McCauley R, Przywara DA, Wakade AR. Adenosine-induced apoptosis in chick embryonic sympathetic neurons: a new physiological role for adenosine. J Physiol 1995; 488: 123-38.

15 Tanaka Y, Yoshihara K, Tsuyuki M, Kamiya T. Apoptosis induced by adenosine in human leukemia HL-60 cells. Exp Cell Res 1994; 213: 242-52.

16 Kohno Y, Sei Y, Koshiba M, Kim HO, Jacobson KA. Induction of apoptosis in HL-60 human promyelocytic leukemia cells by adenosine $\mathrm{A}_{3}$ receptor agonists. Biochem Biophys Res Commun 1996; 219: 904-10

17 Coutinho-Silva R, Perfettini JL, Persechini PM, Dautry-Varsat A, Ojcius DM. Modulation of $\mathrm{P}_{2 Z} / \mathrm{P}_{2} \mathrm{X}_{7}$ receptor activity in macrophages infected with Chlamydia psittaci. Am J Physiol Cell Physiol 2001; 280: C81-9.

18 Maaser K, Hopfner M, Kap H, Sutter AP, Barthel B, von Lampe $\mathrm{B}$, et al. Extracellular nucleotides inhibit growth of human oesophageal cancer cells via $\mathrm{P}_{2} \mathrm{Y}_{2}$-receptors. Br J Cancer 2002; 86: 636-44.

19 Fujita N, Kakimi M, Ikeda Y, Hiramoto T, Suzuki K. Extracellular ATP inhibits starvation-induced apoptosis via $\mathrm{P} 2 \mathrm{X}_{2}$ receptors in differentiated rat pheochromocytoma PC12 cells. Life Sci 2000; 66: 1849-59.

20 Burnstock G. Purinergic signaling and vascular cell proliferation and death. Arterioscler Thromb Vasc Biol 2002; 22: 364-73.

21 Barry CP, Lind SE. Adenosine-mediated killing of cultured epithelial cancer cells. Cancer Res 2000; 60: 1887-94.

22 Wang MX, Ren LM, Shan BE. Effects of extracellular adenosine triphosphate and adenosine on tumor cell proliferation. Chin Pharmacol Bull 2003; 19: 1242-6.

23 Situ ZQ, Wu JZ. Cell Culture. Xi-an: World Book's Publishing Company; 1996. 186-8.

24 Wang CY, Sheng RL, Wang F, Ding XJ, Qiu NL. Fluorescence method of apoptotic morphology studying by acridine orange 
and ethidium bromide double stained cells. Chin J Pathophysiol 1998; 14: 104-6.

25 Kim KT, Yeo EJ, Choi H, Park SC. The effect of pyrimidine nucleosides on adenosine-induced apoptosis in HL-60 cells. J Cancer Res Clin Oncol 1998; 124: 471-7.

26 Fredholm BB, Abbracchio MP, Burnstock G, Daly JW, Harden TK, Jacobson KA, et al. Nomenclature and classification of purinoceptors. Pharmacol Rev 1994; 46: 143-56.

27 Saitoh M, Nagai K, Nakagawa K, Yamamura T, Yamamoto S, Nishizaki T. Adenosine induces apoptosis in the human gastric cancer cells via an intrinsic pathway relevant to activation of
AMP-activated protein kinase. Biochem Pharmacol 2004; 67: 2005-11.

28 Lu GZ, Lin ZX, Zhang ZQ, Zhou LX, Xu GW. Studies on mechanism about ATP inhibited the proliferation of MGC-803 cells. Shi Yan Sheng Wu Xue Bao 1994; 27: 137-9.

29 Abbracchio MP, Ceruti S, Brambilla R, Franceschi C, Malorni W, Jacobson KA, et al. Modulation of apoptosis by adenosine in the central nervous system: a possible role for the $\mathrm{A}_{3}$ receptor. Pathophysiological significance and therapeutic implications for neurodegenerative disorders. Ann N Y Acad Sci 1997; 825: 1122.

\title{
1st International Symposium about Pharmacology of Natural Products (FAPRONATURA 2006)
}

\author{
2006 November 20-24 \\ Varadero, Cuba \\ http://www.scf.sld.cu/natprod/en/portada-en.htm
}

